\section{A unitary theory of stigmatisation}

\author{
Pursuit of self-interest and routes to destigmatisation ${ }^{\dagger}$
}

RAHMAN HAGHIGHAT

\begin{abstract}
Background Stigmatisation is of increasing importance in relation to racism, ageism and sexism but also as an impediment to treating patients.
\end{abstract}

\begin{abstract}
Aims To develop a theoretical foundation to help comprehend the core meaning of stigmatisation and to guide practical anti-stigmatisation measures.
\end{abstract}

Method Personal reflection; re-interpretation of stigmatisation and reformulation of the relevant concepts.

Results Emergence of a unitary theory of stigmatisation.

Conclusions Based on the structure of stigmatisation one could explore six levels of intervention in anti-stigmatisation campaigns: the cognitive level educational intervention; the affective level - psychological intervention; the discrimination level - legislative intervention; the denial level - linguistic intervention; the economic origin political intervention; the evolutionary origin - intellectual and cultural intervention. As destigmatisation has to challenge fundamental human tendencies, anti-stigmatisation campaigns have to be continuous, non-stop, open-ended projects aiming at keeping alive thought processes that moderate and humanise the pursuit of self-interest and the urge to survive in a competitive world.

Declaration of interest Funded by a grant from University College London Trustees.

†See editorial, pp. 197-199, this issue
The impact of stigmatisation nowadays is not what it was when Goffman (1963) was developing his thoughts on stigma. Today in the epoch of cyberspace, websites and real-time communications, we are bombarded with signals and images. Anxiety about being submerged by an everincreasing influx of data makes us codify and categorise more than ever before. Although in-depth and quality understanding are valued, they are sacrificed for pragmatic, cost-effective reasons or to achieve quantitatively defined targets. A steady search for ever-speedier processors, imaging and communication techniques and procedures for compression, transformation and quantification of information means that the human brain is under more stringent demands than those of the mid20th century. In such an atmosphere it may not be seen as 'efficient' to find out whether a person has qualities over and above what the name of their illness implies. The news of a sporadic killing by a patient is instantaneously multiplied by the number of TVs, radios and cyberspace news stations. Compared with a few decades ago, there are more television sets, TV channels, sensationalist programmes and broadcasting times. If in the mid-20th century the word 'schizophrenic' brought to mind the stereotype of a 'mad' person to the exclusion of their other qualities, now it is likely to have a real-time translation into a visual stereotype that is more concrete and more immediate than the semantic stereotype because "cameras don't lie". Twenty-first century patients are acutely aware of the phenomenon of stigmatisation. Delayed help-seeking and nonadherence to antipsychotic medication are among the afflictions of community psychiatry. Today a good number of patients say "I don't want the schizophrenic tablets" not only because of the inconvenience of continuously adhering to a treatment regime or the associated medical side-effects but also because of other side-effects - by taking the medication, they would inevitably endorse the idea that they are 'mad'.

\section{ORIGINS OF STIGMATISATION}

\section{Constitutional origins}

Constitutional factors interfere with the capacity for 'proper' social perception and information processing. After coming across someone disturbed with schizophrenia, are people more likely to think "He was dishevelled and odd" or "He was fit and fast" (when the person has all four attributes)? The intuitive response is that people are more likely to think selectively that the person was "dishevelled" and "odd". Research supports this hypothesis. It is a proven fact that the brain weights negative evaluations in preference to positive ones (Kanouse \& Hanson, 1972). Also, the brain, when overloaded with data, is likely to treat repeated examples of the behaviour of a single person as independent instances of the behaviour of their group (Rothbart et al, 1978), so repeated episodes of violence by one or a few people with mental illness are likely to be interpreted as independent episodes of violence committed by the category of patients with mental illness. Further, the brain, attempting to cope with the influx of data, categorises objects and events in order to economise on resources of memory and perception (Macrae et al, 1994) and to provide quick-and-easy stereotypes at the expense of sophistication and depth.

The brain also tends to associate negative events (which are rarer than neutral and positive events) with other 'rarer' objects, for example with members of minority groups (themselves less numerous and more distinctive) rather than with the majority (Hamilton \& Gifford, 1976; Hamilton \& Sherman, 1989; Stroessner \& Mackie, 1993). This tendency comes from distinctiveness by rarity and the association of distinct events and objects. Thus the brain associates cases of 'crime' (by nature, rarer and more distinctive than instances of 'non-crime') with minorities rather than majorities.

Constitutional factors, in the service of the pursuit of self-interest (Fig. 1), are likely to lead to judgements that are unfair on others, yet they can be adaptive by the very small probability of protection they could offer: for example, one might avoid danger by preferentially weighting negative evaluations about people. 


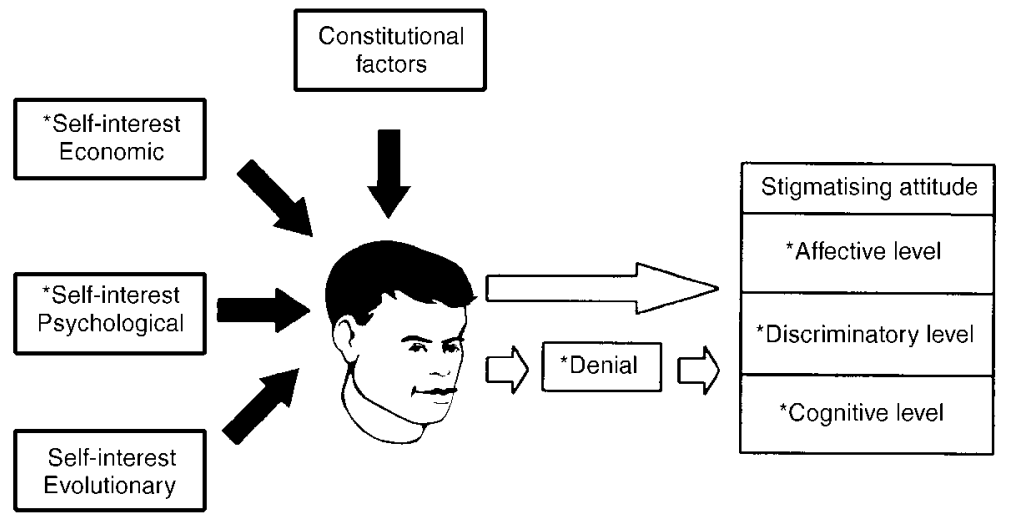

Fig. I Principle of self-interest, structure of stigmatisation and potential targets of anti-stigmatisation campaigns (the latter are denoted by an asterisk).

Constitutional factors, although biological, are considered separately from other evolutionary factors (see below), as the former are more 'vegetative' responses and the scope of anti-stigmatisation in the two areas cannot be the same.

\section{Psychological origins}

Humans, although generally not endorsing the misfortune of others, are willing to use 'unfortunate others' to feel happier about themselves. People in groups in which reward is equally distributed are less satisfied in comparison with people in groups that include an unfortunate person, although they are likely to acknowledge the unfairness of the situation (Brickman, 1975). Further, people subjected to threats, failures and the frustrations of everyday life and those with low self-esteem tend to derogate others in order to bolster their own self-esteem and feelings of well-being (Wills, 1981; Gibbons \& Gerard, 1989). This phenomenon is similar to someone feeling eloquent when he/she considers another inarticulate, or beautiful when he/ she considers another ugly. Thus, stigmatisers benefit from the presence of the stigmatised, the latter providing them with psychological dividends: examples they could consider as 'worse' than themselves in order to redress the balance. On the contrary, people with higher intelligence and higher self-esteem are more likely to hold positive attitudes towards patients with mental illness (Nunnally, 1961), probably because they would not need to degrade those with mental illness in order to feel intelligent or positive about themselves.

Stigmatisers, indeed all of us, when faced with the stigmatised are likely to feel uncomfortable by the mere fact that bizarre behaviour or facial disfigurement, for example, could challenge our norms, values and expectations. To reduce the tension we avoid the stigmatised, which in behavioural terms (Bandura, 1977) means a reduction in tension and thus psychological gain. To deal with any feelings of guilt that this may cause, we may resort to theories such as the Just World hypothesis (Lerner, 1980). The idea that people can experience illness or injury without being responsible threatens us, and we need reassurance that the same fate is not going to befall us. Some of us may then propose that the stigmatised or their parents have done something wrong and are being punished deservedly for their sins. This allows the pursuit of psychological self-interest without unbearable guilt.

Promoting the idea of 'free will' and the concept of self-infliction, e.g. in addictions, although containing partial truth, is indeed used to allay the guilt related to being a stigmatiser and is an application of the Just World belief.

\section{Economic origins}

The stigmatiser's discourse has economic aspects as well. "I must avoid danger to survive and compete": to increase one's access to resources, stigmatisation of rivals is used as a weapon in socio-economic competition (Sherif et al, 1961; Hatfield et al, 1978). Stigmatisation is likely to be more intense in more competitive, self-seeking societies, moderated by the ease of availability of resources. The number of lynchings of Blacks in the USA between 1882 and 1930 varied in line with economic indices such as the value of cotton. As the economy worsened, more Blacks were lynched; as it became better, fewer Blacks were lynched (Hovland \& Sears, 1940; Hepworth \& West, 1988). Of course the relationship between the price of cotton and lynching is a correlation, but what could be the superordinate cause bringing about their covariation? The likely interpretation is that competition for scarce economic resources intensifies hatred and stigmatisation. Again, these disturbing findings are likely to relate to self-interest.

Nowadays, the expression of discrimination may not be lynching. A sports team may accuse another team of drug abuse or disgraceful social behaviour. Here, the former is not necessarily projecting one of its own attributes onto the stigmatised; rather, it may project one out of a list of socially objectionable attributes in order to discredit the rival and promote its own opportunities.

\section{Evolutionary origins}

Stigmatisation, as a tactic for survival and reproduction, is a discourse implying a genetic push towards 'discrimination'. This suggests that genes make humans and animals discriminate in order to avoid dangers, including natural dangers (snakes, heights, darkness), illness (rotten food, those with a contagious disease), mechanical danger (falling objects, those who pose a physical threat) and ideological danger ('deviants', non-conformists and 'psychopaths') (Buss, 1999). Those who are poor bets genetically (carrying genes for a disease), sexually (unattractive, disabled, resourceless), in terms of survival ('social parasites', infected people) and in terms of security ('psychopaths', criminals, exploiters) are avoided (Buss, 1999; Gilbert, 2000) and there is competition with potential rivals for resources, all in the service of genetic interest. Thus, those who are potentially violent because of an underlying mental illness, those who are likely to carry genes for a mental disorder (e.g. manicdepressive illness) and those who are unable to control resources (such as people actively suffering from depression) are stigmatised in the genetic interest of stigmatisers.

\section{EMERGENCE OF A UNITARY THEORY}

In view of the fact that different origins of stigmatisation point to the individual's seeking of personal gain, can it be thought improbable that the fundamental basis of all stigmatisation is the pursuit of selfinterest? Can we doubt (given the fact that self-interest presents as the essence of stigmatisation in all domains) that when there is no pursuit of self-interest there will be 
no stigmatisation and as long as we pursue self-interest we have to face the consequences of our stigmatisation of others?

Stigmatisation involves self-sheltering and self-seeking behaviour. It is a protective device for the stigmatiser and, in a good number of cases, unfair on the stigmatised, as the latter may simply be the victim of a rumour or may not be the one among the stigmatised who would cause harm. The stigmatiser, on each occasion of avoiding the stigmatised, draws primary gain from reducing his or her anxiety and is thus powerfully reinforced. The stigmatiser also draws secondary benefits from stigmatisation by avoiding possible loss, danger and victimisation and by increasing his or her chances of economic survival.

What is the origin of self-interest? Is it biological or acquired? Is it innate or learned? Perhaps a mixture of all? 'Constitutional, psychological, economic and evolutionary' merely constitute a paradigm for the purpose of better understanding, and in practice they all intermingle, overlap, work together and interrelate.

\section{MOTIVATIONS FOR DESTIGMATISATION}

Destigmatisation is a topic of great current interest (Crisp et al, 2000). Does it aim to soften the effects of our stigmatisation of others (our camouflaged 'aggression') or to moderate our guilt? Is 'aggression' an inevitable part of us and benevolence inconceivable other than to moderate its effects? Can the explanation for destigmatisation be that, through identification with the stigmatised we protect ourselves against some susceptibility to stigmatisation on the grounds of our own stigmas? Is destigmatisation encouraged because, through protecting the ill, one promotes group cohesion and the credibility of the state and those in power? Is destigmatisation a way of functionally integrating the stigmatised into the social system without them presenting any threat to the state and its domination? Is destigmatisation expropriation of the problem from those to whom it is claimed to pertain? If the conflict between stigmatisers and stigmatised is about resources, why do stigmatisers (and those in power) try to destigmatise? Does granting destigmatisation confirm the power of whoever grants it? Can one think it improbable that destigmatisation serves the benefits of the stigmatisers as well as of the stigmatised? There are so many possibilities, but there remains one of importance: we destigmatise for love of humanity.

\section{STRUCTURE OF STIGMATISATION}

To develop a solid, goal-oriented antistigmatisation programme one has to have clear ideas about the structure of the stigmatising attitude. The constructive validity of the affective, cognitive and behavioural components of attitudes has been demonstrated by analysis of covariance (Bagozzi, 1978). Like all attitudes, stigmatisation has three components: cognitive (e.g. "schizophrenics are violent"); affective (e.g. anxiety); and discriminatory (e.g. refusing to give someone accommodation). If and when discrimination is exercised, and depending on the stigmatiser's personality, situation and other attitudes (e.g. "I am against prejudice"), stigmatisers are likely to feel some degree of discomfort coming from the discrepancy between their stigmatising attitude and their other attitudes (Monteith, 1996) and in order to reduce the resulting cognitive dissonance they are likely to moderate their stigmatising attitude (Festinger, 1957), to eliminate the awareness of the stigmatising attitude by seeking out information supporting their stereotype (Skov \& Sherman, 1986; Pendry \& Macrae, 1994) or to deny or trivialise their attitude (Simon et al, 1995): "I stigmatise no one".

\section{EDUCATIONAL \\ INTERVENTION}

\section{Enhanced social desirability induced by campaigns of public education}

Trying to change attitudes towards patients with mental illness, some authors found public education to be ineffective (Cumming \& Cumming, 1957; Gatherer \& Reid, 1963; Domino, 1983; Wahl \& Lefkowits, 1989), whereas others reported some effect in the short term (e.g. Morrison et al, 1979, Keane, 1991; Penn et al, 1994; Thornton \& Wahl, 1996; Wolff et al, 1996a). All these studies are bedevilled by an error that one could describe as enhanced social desirability (ESD). Campaigns of public education are likely to enhance the effect of social desirability on people's responses in postcampaign surveys, compared with the same effect in pre-campaign surveys, by the mere fact that during the campaign people are given implicit messages about the objectionability of stigmatisation in so many ways. The effect of ESD is likely to be interpreted subsequently as 'improvement in public attitudes through education'. One can measure ESD from the difference between pre- and post-campaign lie scores, but when it is not measured it is always necessary to entertain its likely distorting effect on the data.

\section{Questionnaires measuring cognition rather than attitudes}

What one measures by 'attitudinal' questionnaires are cognitive hypotheses by subjects themselves of what they would think about, or feel or do towards the general category of patients with (a given) mental illness. The results of the surveys are then neither a measure of behaviour nor a measure of feelings towards the larger group of patients and therefore are not a measure of attitude because the latter has affective and sometimes behavioural components as well. The mind of a person subjected to a cognitive task such as a paper-and-pencil survey is likely to function on a different level than when subjected to the emotional stress of encountering real-life disturbed behaviour. Extrapolating from psychosocial studies (Stephan \& Stephan, 1985; Dijker, 1987; Mackie et al, 1989; Wilder \& Shapiro, 1989; Islam \& Hewstone, 1993), which demonstrated that arousal increases the power of stereotypes and limits access to one's cognitive reserves, one could conclude that the anxiety and fear about personal safety and self-interest resulting from an actual encounter with an acutely ill patient is likely to disperse at least part of the cognitive effect of previous public education.

Yet, cognitions do matter, as the inevitable awareness of the stigmatised of the cognitive elements of people's attitudes puts the former in a position in which they feel vulnerable to what others may choose to do, whether in practice they do it or not.

\section{People selecting the information}

The input that leads to a new emotional experience for the public is likely not to be that they are told that patients are curable but that they do not hear of any more acts of violence committed by someone with mental illness. The development of a cure for mental illness is likely to reduce stigmatisation not when it is just given as cognitive data but when it is shown to be effective. Any 
possible effect of public education is likely to burn out with time as people tend to seek out information that confirms their preexisting stereotypes (Skov \& Sherman, 1986; Pendry \& Macrae, 1994). Data consistent with stigmatising attitudes receive more attention and are rehearsed more frequently (Fiske \& Neuberg, 1990). Although people with a better understanding of mental illness self-reportedly stigmatise less (Link et al, 1987; Brockington et al, 1993), the correlation may mean that those already less likely to stigmatise hold onto the information, confirming their relatively positive stereotypes, rather than that the knowledge per se makes them less likely to stigmatise.

Subjects who show negative attitudes at baseline are likely to refuse to be reinterviewed post-campaign (Wolff et al, 1996a) and information inconsistent with one's stereotype is likely to be refuted or denied (O'Sullivan \& Durso, 1984). In campaigns for changing attitudes towards minority groups (Devine, 1995), the information 'reaches' those who already 'agree' with it. The pressure involved in counterstereotypical messages given to people in anti-stigmatisation protests (Macrae et al, 1996) might make people comply on the surface, while suppressing their stigmatising attitudes, so that overt acts of discrimination are either converted into subtler forms or inhibited, with the possibility of strong rebound (Macrae et al, 1994).

\section{Talking to the feelings versus imparting information}

The stigmatiser, like anyone else, has involuntary, unconditioned emotional responses (arousal, anxiety and fear) to certain events (e.g. serious accidents or death) and conditional responses to whoever reminds them of these events (someone lacking sanity, a mutilated person, a terminally ill person). According to behavioural theory, people take steps to avoid negative events and so the stigmatiser is likely to avoid the stigmatised to get away from the anxiety and fear that they arouse (Berger \& Luckmann, 1966; Schutz, 1971).

Information alone is unlikely to demolish stigmatising attitudes because they are three-storey structures with a cognitive level but with two other levels as well. Anti-stigmatisation is likely to need something deeper than logic. To lecture people that patients with mental illness are not dangerous and that people should not worry about them is like saying to someone who has flight phobia that the aeroplane is safe and that he should not hesitate to board.

Research (Bodenhausen, 1993; Bodenhausen et al, 1994; Jussim et al, 1995) suggests that it is the 'feeling' component rather than the 'cognitive' component of attitudes that determines people's social judgement. Although some stigmatising attitudes are adopted consciously (spreading rumours about an economically rival group), stigmatising attitudes are mostly established through the involuntary process of classical conditioning (Staats et al, 1962), in the same way that phobias are. Thus, if every time one hears the word 'schizophrenic' on TV (conditioned stimulus) there is news of murder (unconditioned stimulus), one is going to associate the fear in relation to the murder (unconditioned response) to the word 'schizophrenic' (conditioned stimulus) and the word is going to bring about the same fear and anxiety (conditioned response) after a certain number of associations.

To make sense of their fear, stigmatisers deploy explanatory models. The cognition that 'schizophrenics are violent' is likely to be part of the subsequent syllogism that stigmatisers use as a semantic back-up for their underlying emotion rather than the cause of it. Offering them the cognitive model 'schizophrenics are not violent' is unlikely to fix the already established autonomic circuit of arousal, fear and anxiety because mere information is likely to fall apart when stigmatisers feel primitive, irrational emotions. They have, in essence, an affective problem. They need a new emotional experience rather than a new 'explanatory model' that they are unable to use and that would not fit their system, however open-minded and scientific the explanatory models of the organisers of a campaign are.

Nevertheless, this idea should not be taken to such extremes as to mean colluding with stigmatisers. Educational campaigns are likely to have, at the very least, the effect of challenging stigmatisers' attitudes, proposing alternative attitudes and emphasising the presence of anti-stigmatisation pressure groups and stakeholders. Psychosocial research on stigmatising attitudes towards ethnic minorities shows that people's awareness of the discrepancy between how they behave and how they think they should behave can cause emotions such as guilt and discomfort, at least in some; this is likely to prevent them from acting on their stigmatising attitude in the future (Monteith, 1996) but without necessarily changing those attitudes. It is likely that what could be achieved by educational campaigns is either nothing or a minor positive shift in moderately negative or relatively positive stereotypes, which then remain open to long-term challenges by constitutional, evolutionary, economic and psychological contingencies based on selfinterest.

\section{INTERVENTION AT THE AFFECTIVE LEVEL}

The public's fear and anxiety as a component of stigmatisation can, theoretically, either be desensitised through contact with patients or relieved through containment and ventilation.

\section{From contacts with patients to exodus from hostel neighbourhoods}

In contacts, the ever-present risk is that of non-generalisation of 'positive' feelings generated towards the stigmatised persons encountered to the category to which they belong. Extrapolating psychosocial findings on students and ethnic minorities (Wilder, 1984; Johnson \& Hewstone, 1992; Van Oudenhoven et al, 1996) to campaigns in mental health suggests that providing the public with contacts with a successfully treated patient is likely to create a new subtype in their mind: "She is an exception. I have seen others worse than her." As exposure to further strong disconfirming examples continues, new subtypes are likely to be created - "female educated patients", "well-treated harmless patients", etc. but the original stereotype is maintained. On the contrary, when the contact person is 'typical' of the stereotype with an additional characteristic of, for example, pleasantness (Wilder, 1984) or when the contact happens in an equal-status cooperative context (Desforges et al, 1991; Van Oudenhoven et al, 1996), there may be a change in the stereotypes.

If substantiated, such hypotheses have to face other challenges in the real world. Among these is the finding that a larger number of examples is required to confirm a positive attribute in a stereotype and fewer contrary examples to disconfirm it (Rothbart \& Park, 1986). This is consistent 
with the fact that people tend to weight negative information more heavily than positive information (Kanouse \& Hanson, 1972). Therefore, exposure to a great number of 'positive' contacts can be undone easily by a few salient items of news about a murder by a patient with mental illness or by a film involving the audience in an emotional contact with characters not elaborated according to social science laboratory formulas. Also, to work from within the stereotype in order to promote its improvement may paradoxically reinforce it because there is a fine line between using the stereotype without giving it undue salience and using it in a way that leads to its further reification.

Wolff et al (1996a) report increased contacts between local patients in a hostel and neighbours as a result of campaigns of public education that encouraged contacts between the two groups. They interpret this as an improvement in overall attitudes and behaviour "towards the mentally ill", taking for granted the generalisation from a few local patients to the category of patients with mental illness. What is also missed is that, after such contacts were encouraged, the mobility of neighbours over a 2-year period was significantly higher than that of people in a control street (Table 1).

Those who moved out had shown no overall difference in stigmatising attitude pre-campaign compared with other neighbours, yet the likelihood that their attitudes were affected more negatively subsequent to the arrival of the hostel and the associated publicity, or that they corresponded to that subgroup who stigmatise in effect and not on survey papers, should not be left unmentioned. Of course, the significant difference in mobility might have occurred due to the presence of a more 'mobile' group in the experimental street at baseline. Mobility is likely to be determined by socio-demographic factors and although there were highly significant disparities between the ethnicity and social class of the control and experimental groups (which already casts serious doubts on the comparability of results) one cannot conclude that the significant excess exodus from the experimental street was merely due to such class and ethnicity differences. The idea that an additional number of neighbours left the experimental street within 2 years to get away from the hostel becomes more probable when one considers that, according to the authors, $20 \%$ of the respondents at the initial interviews expressed concerns, one of which was worry about "a drop in house prices" (Wolff et $a l, 1996 b)$ if patients were moved from hospitals into units in their areas. Although causality between contact and excess exodus cannot be proved, consideration of a significant mobility in an experimental group should be part of the interpretation of any such research. Those who move out of an area to avoid patients can have their negative attitudes reinforced by the mere act of distancing themselves, which would give them a 'feeling of relief' (negative reinforcement). Also noteworthy are the notions of "phantom acceptance" (Goffman, 1963) and specious 'integration' of patients in neighbourhoods with low social cohesion (Segal, 1980), and so high mobility.

The dilemma is clear: on the one hand, if we present the public with dramatically improved patients they are likely to subtype them as 'exceptions'; on the other hand, if we work from within the stereotype and present the public with 'typical' patients, there might be some positive shift in the stereotype but there is also a risk of reinforcing the stereotype.

\section{Focusing on the feelings of the public}

If contacts with patients are fraught with dilemmas, how could one act on the affective level of stigmatising attitudes?

Table I Mobility out of control and experimental streets at the end of the campaign (data derived from Wolff et al, $1996 a$ and re-subjected to statistical analysis)

\begin{tabular}{|c|c|c|c|c|c|}
\hline \multicolumn{2}{|c|}{ Total of both samples $(n=215)$} & \multicolumn{2}{|c|}{ Control street $(n=113)$} & \multicolumn{2}{|c|}{ Experimental street $(n=102)$} \\
\hline \multicolumn{2}{|c|}{ Moved out } & \multicolumn{2}{|c|}{ Moved out } & \multicolumn{2}{|c|}{ Moved out } \\
\hline$n$ & $\%$ & $n$ & $\%$ & $n$ & $\%$ \\
\hline 66 & 31 & 28 & 25 & 38 & 37 \\
\hline
\end{tabular}

$\left(\chi^{2}=3.92\right.$, d.f. $=$ I, $\left.P<0.05\right)$.

When one reflects on the relative success of local targeted efforts at destigmatisation (Lynch, 1987; Quicke et al, 1990), one opportunity is that in these workshop-like events there may have been more opportunity for ventilation of anxieties of some of the target groups. These campaigns, associated with 'discussion' with peers and teachers, reported a more pronounced improvement in 'preconceptions'. There has been no adequate interpretation of why this should be so, yet the likelihood is that during some of these unstructured 'discussions' the fear and anxiety of participants are more or less ventilated. It would not be adequate to tell people that patients are not dangerous, because what they need is to feel free to say how fearful they were the other day when they heard about a patient attacking someone in the street. Real concern for patients starts by paying attention to the affective content of public attitudes. Destigmatisation, if it is ever to be successful, needs to provide forums for the expression of fears, in which people can speak up, ask questions, challenge and communicate their worries. If taken seriously and relieved of their anxiety they are likely to take seriously the same feelings in the patients. Large group meetings with the help of a psychotherapist, facilitator or trained social workers are likely to allow ventilation of public feelings in neighbourhood centres, youth organisations, community services, churches, libraries and schools.

\section{Labouring in the arts' workshop}

The arts would identify its function as not always copying reality but as modifying and representing it in new forms. An aspect of work on the affective component of the stigmatising attitude would be to acquire a weapon: producing works of art, writing popular novels or making films with the help of interested patients and psychiatrists in collaboration with artists. These works of art are likely to act on the feelings of the public at a level where the affective component of their attitude resides, rather than at a cognitive level. There is much scope for acting on the public's feelings by portraying the struggle and revaluation of patients with mental illness. A relevant example is The Marie Butler Story, a film produced in the USA by CBS in collaboration with the National Alliance for the Mentally Ill (NAMI) about the sacrifices and successes of an 'institutionalised' 
woman. The risk of subtyping is likely to reduce when works of art depict a 'typical' patient with 'typical' struggles who improves and develops into a person seen by viewers and readers as someone like themselves. Work with TV professionals needs to be a business of having anti-stigmatising messages subsumed under new emotional experiences for the viewers. Generous arts and media awards would guarantee cooperation.

\section{LEGISLATIVE INTERVENTION}

In theory, legislation both reflects and moulds public attitudes. To date, there has been little experimental evidence showing that anti-discrimination legislation would or would not change public stereotypes. It is possible that new laws contrasting with personal attitudes would challenge people into debate and self-questioning. To avoid legal sanction, people would have to bring their behaviour at least in line with the law and this would cause dissonance with the previous attitude (Festinger, 1957). The final outcome in some cases is likely to be a change of attitudes, but in most cases the public would choose the easiest route: holding onto their pre-existing attitudes while justifying their new behaviour with the necessity to avoid the sanctions in force. Thus, anti-discrimination laws acting as symbols of 'parental' authority and judgement could merely suppress stigmatising attitudes but at the same time they are likely to function as institutional support (Allport, 1954), protecting patients from injustice and increasing the public tendency, through internalisation of a new behavioural norm (even while holding onto the old attitude), to act in a more egalitarian manner.

The exercise of discrimination can be subtle, such as sitting apart or not smiling, or flagrant, such as rejection of an employment application or refusing to rent out accommodation or not allowing people on public premises. The legislative system needs to be encouraged and/or put under pressure through advocacy and lobbying by anti-stigmatisation watch-dogs created within psychiatric associations. The latter, networking lawyers, members of parliament and human rights organisations should identify gaps in the legal protection and promote enacting laws that allocate sanctions on gross discriminatory behaviour. Other legislation needs to promote positive discrimination in the sense that employers should be rewarded for having a quota of employees from those who suffer from mental illness and providing them with training options and specific sick-leave provisions; landlords should have more obligation towards patients; and insurance companies should have some commitment to include cover for mental illness on their mainstream policies as a means of recognising the value of people with mental health problems and the ubiquity and acceptability of mental illness.

\section{POLITICAL INTERVENTION}

Pathology in a nation is likely to be related in part to biopsychosocial factors (Engel, 1980), including the nature of the political system, civil liberties and social justice, which reflect and are in turn reflected by the quality of upbringing and emotional stability within families. It is likely that a society based on warmth and intimacy rather than dominance and power has less need to systematically pursue self-interest and to stigmatise. On the contrary, in highly competitive environments where self-interest is intensely pursued, discrimination is likely to rise, with consequent poorer prognosis, inasmuch as the stigmatisers are perceived as a bigger threat to self-interest and are further rejected. The attitude of the state to the extent and implications of interindividual competition is likely to influence the citizens' attitudes, and vice versa. For example, intervention of the state to limit ruthless, cruel or extravagant economic takeovers that threaten the survival of individuals and smaller businesses and the state's allocation of substantial budgets to anti-discriminatory activities would be a message to the whole society about the effects of aggressive competition and/or destruction of the chances of the weak.

Egalitarian non-competitive environments that encourage cooperative interdependence of all people for a superordinate aim of rewarding the whole society reduce inter-group hostility and prejudice (Sherif, 1966; Amir, 1976; Gaertner et al, 1993). The political philosophy of the state and its emphasis on unity and interdependence of people is likely to moderate the selfserving behaviour of its citizens and promote tolerance and respect for all, including the weak and the vulnerable, who are then seen as allies in the service of the higher cause. This is ambitious enough for it to be a task to which all citizens need to contribute, the task of the third millennium.

What we perhaps lack is a political ideology that would allow consideration of the environments from which people come rather than how much they have achieved. In many contexts, an important question all of us need to answer is whether the existential value of someone who has achieved more without having a mental illness is necessarily higher than that of another who has achieved less while having a mental illness. The difficulties facing some people with mental illness are just the same as those that would face anyone who developed mental illness after a lifetime of good mental health, and they cannot be used as a basis for measuring people's personal value.

\section{LINGUISTIC INTERVENTION}

The biggest misunderstanding in debates on 'political correctness' seems to be the misconceived idea that the whole aim of linguistic intervention is to reduce the verbal disrespect towards the stigmatised. There is a well-known history of repetitive changes of designations for people with learning difficulty, each new term acquiring, after some time, the discrediting connotations of the previous ones. Yet, the effect of change of a designation is desirable, even if it is temporary. Linguistic intervention can be a tactic of scratching at the surface, with the strategy of looking at the core. As such, it aims at engaging people in a discourse of value as a means of promoting shifts in attitudes.

Linguistic intervention challenges and invites at the same time: challenges whoever has a stigmatising attitude, and invites whoever might be sympathetic enough to join the destigmatisers. Thus, to favour the use of 'a person with an experience of schizophrenia' as opposed to 'schizophrenics' is not necessarily mistaking linguistic symptoms for the social reality of the lives of these patients.

Reviewing brochures of advocacy organisations such as Mind (National Association for Mental Health) shows that linguistic intervention is one of the requests of patients and their advocates, and destigmatisation starts by paying attention to these requests. In changing their 'titles', patients assert that the existing orders of the world are not immutable and this can be their first step towards more autonomy. 
Their request does not need to be taken as a mere wish for a change of designation (Haghighat \& Littlewood, 1995); it can also be seen as a tacit invitation by patients to others to review their stereotypes, indeed a request for a reconsideration of others' personal attitudes. In this perspective, linguistic intervention is an attempt to launch a debate on something 'wrong' in stigmatisers' language in order to draw attention to something more sinister: a self-enquiry device that challenges the denial. As is the case with anti-stigmatisation protests (Macrae et al, 1996), linguistic intervention may lead to suppression of stigmatising attitudes, yet, unlike educational campaigns, this would not necessarily remain a pure cognitive enterprise in that it directly challenges stigmatising attitudes and is likely to arouse more emotions (e.g. constructive guilt) in some people and have at least some positive effect.

\section{INTELLECTUAL AND CULTURAL INTERVENTION}

Novel interpretations of evolution would limit deterministic features imposed on our views by current interpretations, which can tacitly serve stigmatisers. Sociobiology considers a variety of animal and human behaviours and tries to interpret them along the lines of the theory of survival of 'selfish genes', which use our bodies as robots, making us behave in ways leading to the ruthless self-replication of these genes. Explaining stigmatisation as one aspect of a genetic behavioural programme for the survival of genes implies that isolating and rejecting the stigmatised is a natural evolutionary process, 'justifying' prejudice as something 'biological' and 'innate' and reifying stigmatisation as a more or less deterministic ideology.

The fact that nature is what it is does not mean that one could not use judgement or morality to decide what is good for humans (Barash \& Lipton, 1985). Yet, those who need to stigmatise in order to dominate would either downgrade the idea of morality as the instrument used by the weak (Nietzsche, 1886) or recommend a new 'morality' in the service of power: "one has duties only toward one's equals; one may act as one sees fit toward beings of a lower rank, toward everything foreign to one" (Nietzsche, 1886). Thus, 'old' and 'new' morality can both be used in the service of domination. The Encyclopaedia
Britannica (1998) mentions that "two books were standard issue for the rucksacks of German soldiers during World War I, Thus Spoke Zarathustra [by Nietzsche] and The Gospel According to St. John". Later on, Nietzsche's views and social Darwinism (used to proclaim that helping the weak was against natural selection) were employed by the Nazi system to provide ideological underpinnings for the thesis of the superiority of Aryan races (Encyclopaedia Britannica, 1998) and the extermination of six million Jews.

Although the seeking of self-interest remains the basis of stigmatisation, the genetic origin of stigmatisation is not as deterministic as is sometimes implied. If genes can guarantee their own survival through encouraging the reproduction of people with similar or closely related genes, then how do we explain the high level of violence in families? Also, some people choose dangerous hobbies and pursuits for self-fulfilment purposes even if they might lose their lives in the process, which, of course, would not lead to any genetic interest. There is no evidence that the numbers of such people are reducing nor that the ultimate 'logic' in having these dangerous hobbies is necessarily to attract the opposite gender and propagate one's genes. Also, there are people who choose not to have children, cutting back, in effect, the 'hope' of their species' genes to self-replicate while they compete ardently on economic grounds, and there is no more reason to believe that they do so (unawares) for others to procreate on their behalf (like worker bees who sacrifice their fertility for the sake of their queen to procreate) than they do so on account of their own fulfilment.

Viruses, protozoa and even higher animals are highly restricted by the fiat of their genome and lack the human freedom for intervening intellectually, ideologically or scientifically in the workings of their own genes or gene products. Humans are relatively freed from the hegemony of genes and are offered, through evolution, more space, options and alternatives in choosing their own behaviour and destiny. This idea that evolution has an unrelenting tendency towards releasing higher species, especially humankind, from biological constraints is of pivotal significance for the reconstruction of a new discourse for modern evolution. It is ideology that decides how we are going to use our relative freedom from the biological imperatives that still restrict the animal kingdom. Ideology is not genetic and, even if it were proved to be, there would always be the possibility of choice between the countervailing ones.

In ideologically favourable societies, opting for non-stigmatising behaviours could have reproductive value. A change of culture may render 'ancient' adaptive mechanisms irrelevant for survival in modern circumstances. Culture can design environments that would lead to the selection not of stigmatisers but of cooperative interdependent protagonists. Indeed, groups whose members cooperate with one another may out-produce groups composed of selfish individuals (Sober \& Wilson, 1998). What hinders a more equitable approach to other humans can only be the vestiges, in our genome, of our animal evolutionary heritage, whereas deployment of our newly acquired evolutionary autonomy can help us to develop cultures that promote destigmatisation.

\section{ACKNOWLEDGEMENT}

I would like to thank Professor Roland Littlewood for his encouragement of this work.

\section{REFERENCES}

Allport, G. (1954) The Nature of Prejudice. Cambridge, MA: Addison-Wesley.

Amir, Y. (1976) The role of intergroup contact in change of prejudice and ethnic relations. In Towards the Elimination of Racism (ed. P. Katz). New York: Pergamon Press.

Bagozzi, R. P. (1978) The constructive validity of the affective, behavioral and cognitive components of attitudes by analysis of covariance structure. Multivariate Behavioral Research, 13, 9-31.

Bandura, A. (1977) Social Learning Theory. Englewood Cliffs, NJ: Prentice-Hall.

Barash, D. P. \& Lipton, J. (1985) Sociobiology. In Comprehensive Textbook of Psychiatry (eds H. I. Kaplan \& B. J. Sadock), p. 70. Baltimore, MD: Williams \& Wilkins.

Berger, D. L. \& Luckmann, T. (1966) The Social Construction of Reality: A Treatise in the Sociology of Knowledge. New York: Doubleday.

Bodenhausen, G. F. (1993) Emotion, arousal, and stereotypic judgment: a heuristic model of affect and stereotyping. In Affect, Cognition and Stereotyping: Intergroup Processes in Intergroup Perception (eds D. Mackie \& D. Hamilton), pp. 13-37. San Diego, CA: Academic Press.

_, Kramer, G. P. \& Susser, K. (1994) Happiness and stereotypic thinking in social judgment. Journals of Personality and Social Psychology, 66, 62I-632.

Brickman, P. (1975) Adaptation level determinants of satisfaction with equal and unequal outcome distributions in skill and chance situations. Journal of Personality and Social Psychology, 32, 191-198.

Brockington, I. F., Hall, P., Levings, J., et al (1993) The community's tolerance of the mentally ill. British Journal of Psychiatry, 162, 93-99. 
Buss, D. (1999) Evolutionary Psychology. Boston, MA: Allyn \& Bacon.

Crisp, A. H., Gelder, M. G., Rix, S., et al (2000) Stigmatisation of people with mental illness. British Journal of Psychiatry, I77, 4-7.

Cumming, E. \& Cumming, J. (1957) Closed Ranks an Experiment in Mental Health Education. Cambridge, MA: Harvard University Press.

Desforges, D. M., Lord, G. C., Ramsey, S. L., et al (199I) Effects of structured cooperative contacts in changing negative attitudes towards stigmatised groups. Journal of Personality and Social Psychology, 60. 531-544.

Devine, P. G. (1995) Prejudice and out-group perception. In Advanced Social Psychology (ed. A Tesser), pp. 467-524. New York: McGraw-Hill.

Dijker, A. J. M. (1987) Emotional reactions to ethnic minorities. European Social Psychology, 4, I-10.

Domino, G. (1983) Impact of the film 'One Flew Over the Cuckoo's Nest' on attitudes towards mental illness. Psychological Reports, 53, 179-182.

Encyclopaedia Britannica (1998) Encyclopaedia Britannica, CD 98. Chicago, IL: Encyclopaedia Britannica.

Engel, G. L. (1980) The clinical application of biopsychosocial model. American Journal of Psychiatry, 137, 535-544.

Festinger, L. (1957) A Theory of Cognitive Dissonance. Evanston, IL: Row, Peterson.

Fiske, S. T. \& Neuberg, S. L. (1990) A continuum model of impression formation, from category-based to individuating processes: influence of information and motivation on attention and interpretation. In Advances in Experimental Social Psychology (ed. M. P. Zanna), vol. 23. New York: Academic Press.

Gaertner, S. L., Rust, M. C., Dovidio, J. F., et al (1993) The contact hypothesis: the role of a common in-group identity on reducing inter-group bias. Small Group Research, 25, 224-249.

Gatherer, A. \& Reid, J. J. A. (1963) Public Attitudes and Mental Health Education. Northampton: Northamptonshire Mental Health Project.

Gibbons, F. X. \& Gerard, M. (1989) Effects of upward and downward social comparison on mood states. Journal of Social and Clinical Psychology, I, |4-31.

Gilbert, P. (2000) The origins of stigmatisation: stigmatisation as a survival strategy. Shame, stigma and the family: 'skeletons in the cupboard' and the role of shame. In Every Family in the Land: Tackling Prejudice and Discrimination Against People with Mental Illness (ed. A. H. Crisp). www.stigma.org.

Goffman, E. (1963) Stigma: Notes on the Management of Spoiled Identity. Englewood Cliffs, NJ: Prentice-Hall.

Haghighat, R. \& Littlewood, R. (1995) What should we call patients with schizophrenia? A sociolinguistic analysis. Psychiatric Bulletin, 19, 407-410.

Hamilton, D. L. \& Gifford, R. K. (1976) Illusory correlation in interpersonal perception: a cognitive basis of stereotypic judgments. Journal of Experimental Social Psychology, 12, 392-407.

_ \& Sherman, S. J. (1989) Illusory correlations: implications for stereotype theory and research. In Stereotyping and Prejudice: Changing Conceptions (eds D. Bar-Tal, C. F. Graumann, A.W. Kruglanski, et al), pp. 59-82. New York: Springer Verlag.

Hatfield, E., Walster, G. W. \& Berscheid, E. (1978) Equity: Theory and Research. Boston: Allyn \& Bacon.

Hepworth, J.T. \& West, S. G. (1988) Lynchings and the economy: a time-series reanalysis of Hovland and

\section{CLINICAL IMPLICATIONS}

- The article presents a novel theory of stigmatisation that helps in understanding how patients are deployed as a commodity for other people's self-interest.

- It provides an account of several domains and in each is able to cover the relevant evidence and lead to new predictions.

- The unitary formulation has the double advantage of tenability and coverage and generates fruitful avenues of research.

\section{LIMITATIONS}

Assessing the relative efficacy of different anti-stigmatisation interventions is beyond the scope of this article.

- Long-term follow-up studies on destigmatisation have not been performed so far.

- Not all the potential core issues in stigmatisation could be addressed, owing to space limitations.

RAHMAN HAGHIGHAT, MRCPsych, Department of Psychiatry and Behavioural Sciences, Middlesex Hospital, London

Correspondence: Rahman Haghighat, Adult Department, Tavistock Clinic, 120 Belsize Lane, London NW3 5BA, UK. E-mail: r. haghighat@lycos.com

(First received 29 March 2000, final revision 26 June 2000, accepted 28 June 2000)

Sears (1940). Journal of Personality and Social Psychology, 55, 239-247.

Hovland, C. L. \& Sears, R. R. (1940) Minor studies in aggression: Vl. Correlation of lynchings with economic indices. Journal of Psychology, 9, 301-310.

Islam, M. R. \& Hewstone, M. (1993) Dimensions of contact as predictors of intergroup anxiety, perceived out-group variability and outgroup attitude: an integrative model. Personality and Social Psychology Bulletin, 19, 700-710.

Johnson, L. \& Hewstone, M. (1992) Cognitive models of stereotype change: subtyping and the perceived typicality of disconfirming group members. Journal of Experimental Social Psychology, 28, 360-386.

Jussim, L., Nelson, T. E., Manis, M., et al (1995) Prejudice, stereotypes and labeling effects: sources of bias in person perception. Journal of Personality and Social Psychology, 68, 228-246.

Kanouse, D. E. \& Hanson, L. R., Jr. (1972) Negativity in evaluations. In Attributions: Perceiving the Causes of Behaviour (eds E. E. Jones, D. E. Kanouse, H. H. Kelley, et al), pp. 47-62. Morristown, NJ: General Learning Press.

Keane, M. (1991) Acceptance vs. rejection: nursing students' attitudes about mental illness. Perspectives in Psychiatric Care, 27, 13-18.

Lerner, M. J. (1980) The Belief in a Just World: A Fundamental Delusion. New York: Plenum Press.

Link, B. G., Cullen, F. T., Frank, J., et al (1987) The social rejection of former mental patients: understanding why labels matter. American Journal of Sociology, 92, $1461-1500$.
Lynch, J. (1987) Prejudice Reduction and the Schools. London: Cassell.

Mackie, D. M., Hamilton, D. L., Schroth, H. H., et al (1989) The effects of induced mood on expectancybased illusory correlations. Journal of Experimental Psychology, 25, 524-544.

Macrae, C. N., Bodenhausen, G.V., Milne, A. B., et al (1994) Out of mind but back in sight: stereotypes on the rebound. Journal of Personality and Social Psychology, 26, 289-304.

et al (1996) On resisting the temptation to simplification: counterintentional effects of stereotype suppression on social memory. Social Cognition, 14, I-20.

Monteith, M. J. (1996) Affective reactions to prejudiced-related discrepant responses: the impact of standard salience. Personality and Social Psychology Bulletin, 22, 48-59.

Morrison, J. K., Becker, R. E. \& Bourgeois, C. A. (1979) Decreasing adolescents' fear of mental patients by means of demythologizing. Psychological Reports, $\mathbf{4 4}$ 855-859.

Nietzsche, F. (1886) Beyond Good and Evil: Prelude to a Philosophy of the Future (trans. R. J. Hollingdale). Harmondsworth: Penguin.

Nunnally, J. (1961) Popular Conceptions of Mental Health: Their Development and Change. New York: Holt, Rinehart \& Winston.

O'Sullivan, C. S. \& Durso, F. T. (1984) Effects of schema-incongruent information on memory for stereotypical attributes. Journal of Personality and Social Psychology, 47, 55-70. 
Pendry, L. F. \& Macrae, C. N. (1994) Stereotypes and mental life: the case of the motivated but thwarted tactician. Journal of Experimental Social Psychology, 30 303-325

Penn, D. L,., Guynan, K., Daily, T., et al (1994)

Dispelling the stigma of schizophrenia: what sort of information is best? Schizophrenia Bulletin, 20 567-577.

\section{Quicke, J., Beasley, K. \& Morrison, C. (1990)}

Challenging Prejudice through Education: The Story of Mental Handicap Awareness Curriculum Project. Bristol, PA: Falmer Press.

Rothbart, M. \& Park, B. (1986) On the confirmability and disconfirmability of trait concepts. Journal of Personality and Social Psychology, 50, 131-142.

\section{— , Fulero, S., Jensen, C., et al (1978)}

From individual to group impressions: availability

heuristics in stereotype formation. Journal

of Experimental Social Psychology, 14, 237-255.

Schutz, A. (1971) Collected Papers, Vol. I: The Problem of Social Reality. The Hague: Martinus Nijhoff.

\section{Segal, S. P., Baumohl, J. \& Moyles, E. (1980)}

Neighborhood types and community reactions to the mentally ill: a paradox of intensity. Journal of Health and Social Behavior, 2I, 345-359.

Sherif, M. (1966) Group Conflict and Cooperation: Their Social Psychology. London: Routledge \& Kegan Paul.

\section{_ , Harvey, O. J., White, B. J., et al (1961)} Inter-group Conflict and Cooperation: The Robbers Cave Experiment. Norman: University of Oklahoma Book Exchange.

Simon, L., Greenberg, J. \& Brehm, J. (1995)

Trivialization: the forgotten mode of dissonance reduction. Journal of Personality and Social Psychology, 68 247-260.

Skov, R. B. \& Sherman, S. J. (1986) Informationgathering processes: diagnosticity, hypothesisconfirmatory strategies, and perceived hypothesis confirmation. Journal of Experimental Social Psychology, 22, 93-121.

Sober, E. \& Wilson, D. S. (1998) Unto Others: The Evolution and Psychology of Selfish Behaviour. MA: Harvard University Press.

Staats, A. W., Staats, C. K. \& Crawford, H. L. (1962) First-order conditioning of meaning and the parallel conditioning of GSR. Journal of General Psychology, 57, |59-167.

Stephan, W. \& Stephan, C.W. (1985) Intergroup anxiety. Journal of Social Issues, 4I, I57-175.

Stroessner, S. J. \& Mackie, D. M. (1993) Affect and perceived group variability: implications for stereotyping and prejudice. In Affect, Cognition, and Stereotyping: Interactive Processes in Group Perception (eds

D. M. Mackie \& D. L. Hamilton), pp. 63-86. San Diego, CA: Academic Press.
Thornton, J. A. \& Wahl, O. F. (1996) Impact of a newspaper article on attitudes toward mental illness. Journal of Community Psychology, 24, 17-24.

\section{Van Oudenhoven, J. P., Groenwoud, J.T. \&}

Hewstone, M. (1996) Cooperation, ethnic salience and generalisation of interethnic attitudes. European Journal of Social Psychology, 26, 649-661.

Wahl, O. F. \& Lefkowits, J.Y. (1989) Impact of a television film on attitudes about mental illness. American Journal of Community Psychology, 17, 521-528.

Wilder, D. A. (1984) Intergroup contact: the typical member and the exception to the rule. Journal of Experimental Social Psychology, 20, 177-94.

_ \& Shapiro, P. N. (1989) Effects of anxiety on impression formation in a group context: an anxiety assimilation hypothesis. Journal of Experimental Social Psychology, 25, 48I-499.

Wills, T. A. (1981) Downward comparison principles in social psychology. Psychological Bulletin, 90, 245-27I.

Wolff, G., Pathare, S., Craig, T. et al (1996a) Public education for community care: a new approach. British Journal of Psychiatry, 168, 44I-447.

$\ldots, \ldots, \ldots$, et al (1996b) Who's in the lion's den? The community's perception of community care for the mentally ill. Psychiatric Bulletin, 20, 68-7l. 